\title{
Lusotopie, Lusotopy. What Legacy, What Future?
}

\author{
Michel Cahen \\ Directeur de recherche, LAM, UMR 5115, CNRS/Sciences Po Bordeaux, Pessac, \\ France \\ m.cahen@sciencespobordeaux.fr \\ Irène Dos Santos \\ Chargée de recherche, URMIS, UMr 8245, CNRs/Université Paris-Diderot, \\ France \\ irene.dossantos@cnrs.fr
}

\begin{abstract}
The introduction of this issue goes back over the history of the creation of the Lusotopie journal. It also questions the scope of the concept of lusotopy in the social sciences. The intellectual project of the journal, published from 1994 onwards, was complex and ambitious. Lusotopie is not a review of "cultural-area" studies, but a generalist review of political analysis, in the broadest sense, from an empirically-delimited research field: that of the area drawn by Portuguese history and colonization. It was both to escape the contemporary neo-imperial approach of "Lusophony" and to overcome the simply negative criticism of the ideology of Lusophony (in its literary, political and economic aspects), which as such does not provide a tool for understanding the realities produced by history.
\end{abstract}

\section{Keyword}

Lusotopie journal - social sciences - cultural-area studies - Lusophony - lusotopy post-colonial 


\section{Lusotopie, Lusotopie. Quel héritage, quel futur?}

\section{Résumé}

L'introduction de ce dossier revient sur l'histoire de la création de la revue Lusotopie et interroge la portée du concept de lusotopie dans les sciences sociales. Le projet intellectuel de la revue, publiée à partir de 1994, était complexe et ambitieux. Lusotopie n'est pas une revue d'« aire culturelle » mais une revue généraliste d'analyse politique, au sens large, à partir d'un terrain empirique de recherche, celui de l'aire dessinée par l'histoire et la colonisation portugaises. Il s'agissait à la fois d'échapper à l'approche néo-impériale contemporaine de la «lusophonie » et de dépasser la critique simplement négative de l'idéologie de la lusophonie (dans ses aspects littéraires, politiques et économiques) qui ne fournit pas, en tant que telle, un outil pour comprendre des réalités produites par l'histoire.

\section{Mots-clefs}

revue Lusotopie - sciences sociales - études d'aire culturelle - lusophonie - lusotopie post-colonial

\section{Lusotopie, Lusotopia. Que legado, que futuro?}

\section{Resumo}

A introdução deste dossiê retoma a história da criação da revista Lusotopie e interroga a pertinência deste conceito nas ciências sociais. O projeto intelectual da revista, publicada a partir de 1994, era complexo e ambicioso. Lusotopie não é uma revista pesquisando uma "área cultural", mas uma revista generalista de análise política no sentido lato, a partir de um terreno empírico de investigação da área traçada pela história e pela colonização portuguesa. Tratava-se, simultaneamente, de evitar a leitura neoimperial contemporânea da "lusofonia" e de ultrapassar a crítica simplesmente negativa da ideologia da lusofonia (nos seus aspetos literários, políticos e económicos), já que esta não fornece, por si só, um instrumento que permita compreender as realidades produzidas pela história. 


\section{Palavras chaves}

revista Lusotopie - conceito - estudo de terreno - área cultural - lusofonia pós-colonial - ciências sociais

In 1991-1992, Christine Messiant, a sociologist at the École des Hautes Études en Sciences Sociales (School of Advanced Studies in the Social Sciences, EHESS), Christian Geffray, an anthropologist who was soon to be recruited by the Institut de Recherche pour le Développement (Institute for Development Research), and Michel Cahen, an historian at the Centre National de la Recherche Scientifique (National Centre for Scientific Research, CNRS) and a researcher at what was then the Centre of Black African Studies at the Institut d'Études Politiques de Bordeaux (Institute of Political Science at Bordeaux), put together a proposal for a new journal. The objective, in the broadest sense, was the political analysis of the spaces and communities produced or shaped by the history of Portuguese colonial expansion. Messiant was an authority on Angola, Geffray was a specialist on Mozambique, and Cahen's work focussed on Mozambique as well as on Portuguese colonialism generally: there was nobody in the group, therefore, who was a specialist on metropolitan Portugal or Brazil, to say nothing of Portuguese-speaking Asia. Despite this, the projected journal was by no means limited to an African focus. It was not by chance that the journal was conceived in this particular fashion - none of the founders were literary scholars, none of them accepted the idea of Lusophony - the so-called Portuguesespeaking world - uncritically. What they wanted to do was to break with the compartmentalization which, at least in France, had resulted in a tradition of Portuguese Studies that was mainly literary, and a tradition of Brazilian Studies that was principally anthropological. The idea was not to establish a political science journal, but rather to deploy the entire arsenal of the social sciences to understand political issues in the heterogeneous space shaped by centuries of Luso-Brazilian history. ${ }^{1}$ Nor, despite appearances, was the intention to establish a "cultural-area studies" journal.

At that time, in the 1990s, cultural-area studies were both fashionable and unfashionable among researchers and institutions (but not always at the

1 What we mean by "Luso-Brazilian" history, empirically speaking, is the history of imperial Portugal, which included Brazil and from which it drew half of its resources - an empire that was thus mainly Brazilian - and then, after 1822, the parallel but still interconnected histories of Portugal and Brazil. 
same time). ${ }^{2}$ What was striking about this situation was that the very simple question - do cultural areas actually exist? - was never posed. The answer needed to be extremely nuanced and relative. At the beginning of the 199os, in the middle of various projects to restructure public research in France, the experts had decided that it was necessary to identify "themes" and to discard "cultural-area studies". The debate was poorly conceptualised: obviously what was needed was to take both approaches into account, and not necessarily according to a simple intersection of research interests.

First, the debate was extremely Eurocentric (or perhaps even "centrocentric"). It quickly became apparent that whatever was thematic, was in fact so in relation to Europe or to the West (the centre of the world). To work on this or that aspect of French or American political history, was then and still is today to be a generalist and a proponent of thematic research, while somebody who worked on India or the Portuguese-speaking African countries (Paises africanos de língua oficial portuguesa; the PALOPs) would be a specialist narrowly tied to a cultural area. It is worth noting that, for once, a very similar debate to the one we had in France took place in the United States.

In fact, in the United States, the rise of area studies had initially been a means of asserting the general relevance of research on subaltern areas; it was also a way of giving jobs to researchers, often from the Third World, who devoted themselves to it. Nevertheless, attention must be drawn to the fact that in the United States the term used was "area studies" and this was not in any way a specialization in cultural areas. Area studies are empirically delimited according to the object of study, but the cultural area is from the beginning diagnostic, judgmental - a broadly colonial approach. This is because the concept relies on a single marker of identity, the result of colonization ("la francophonie", "a lusofonia", and even "Africa" or "Asia", perceived as Orientalised and essentialised within the clash/dialogue of civilizations, and so on). From this perspective, we can only quote approvingly Jean-Pierre Chrétien's methodological position, concerning one of these "areas" (Africa) in his editorial in the first number of the journal Afrique et Histoire in 2003:

Africa is involved in the Atlantic world, the Mediterranean world, the Arab, Indian and Indonesian areas. It is not a "cultural area", it is a historically-constructed continental space, which is to say economically,

2 While the notion of a cultural area, at least as a basis for the existence of research centres, was the object of debate by researchers, a few years later the CNRS management placed such areas at the top of its list of priorities, going against the tendency towards a thematic focus mentioned here. 
socially, politically and culturally. This "invention" has a history. But it is not only played out in the eyes of observers, even if they are African, it is played out on a daily basis, and so the spaces expand from the most "universal" to the most "particular", within the framework of a "social" history in the broadest sense, a history of the construction of social bonds of every kind and the forms of identity and the world views linked to them.

CHRÉTIEN 2003: 17

Thus, Africa is not a cultural area, but an empirically-delimited research space, defined above all by its specific place in the world-economy. In other words, there are as many cultural differences between Senegal and Mozambique as there are between Portugal and Azerbaijan, but nobody would dream of locating the latter two countries in the same cultural area. Nonetheless, we often do exactly that with regard to the former two.

Second, the necessary articulation between a generalist contribution to the development of one or another of the social and human science disciplines, and its rootedness in a terrain, was poorly formulated for a debate in favour of or opposed to cultural areas. It was still necessary to show how rootedness in a terrain, even if it was a composite one, might just be the best of all general and thematic contributions.

The group of researchers around what was to become the journal Lusotopie, finally launched in July 1992, was subsequently joined by François Guichard and Louis Marrou (geographers specialising in Portugal) and Déjanirah Couto (an historian, focussing on Asia). ${ }^{3}$ The group immediately found itself located at the centre of the problematic, since it had never understood "Lusophony" as a cultural area, but rather as the historical meeting point of political trajectories - or to use the elegant formulation of the Portuguese essayist Eduardo Lourenço, "a specific area of intersection with other identities". ${ }^{4}$ It is by no means coincidental that the concept of lusotopy ${ }^{5}$ was first suggested by the geographer Louis Marrou (Université de La Rochelle) at the group's founding meeting. The reader will find in this book a very personal text of his, a sort of intimate and intellectual journey "in lusotopy". The term defines countries or communities that, in the course of their history, have been shaped or marked

3 The group was hit hard by the deaths among its founders of Christian Geffray at the age of 46 on 9 March 2001, of François Guichard at the age of 55 on 23 March 2002, and of Christine Messiant at the age of 58 on 3 January 2006.

4 Notes by Michel Cahen on the intervention of Eduardo Lourenço during the first study workshop of Lusotopie, Paris, Sorbonne, 14-15 December 1996.

5 We choose to translate the word lusotopy in this way to "unfrenchify" it and make the concept available in different languages. 
by Luso-Brazilian expansion, regardless of whether their populations (or even states) still use Portuguese today or not. The Agudas of Benin and Togo have not spoken Portuguese for over a century, nobody speaks Portuguese in Goa, and very few people spoke it in Mozambique or Timor at the time the journal was founded. Nonetheless, these territories are part of lusotopy because with almost every step, one stumbles upon Portuguese heritage.

On its back cover and in three languages (French, Portuguese and English), the new journal, Lusotopie, explained its methodology: "Lusotopie is an international comparatist journal devoted to political analysis of contemporary spaces stemming from Portuguese history and colonization. It deals with general issues in political analysis (nationalism, ethnicity, neo-liberalism, State reform, federalism, gender, civil war, media, civil society, elections; etc.): it provides an original approach within this heterogeneous postcolonial space on the four continents and in numerous diasporas."

Lusophony, therefore, is certainly an "area", but delimited only as a post-colonial ${ }^{6}$ space, itself indefinable except perhaps, as has already been pointed out, as a specific area of intersection with multiple other identities, as proposed by Eduardo Lourenço (European, African, Latin American, Native American, Asian, religious, and so on). In a recent article discussing this issue, Michel Cahen (2007) defined Lusophony as follows:

Lusophony is definitely not a cultural area, but a specific post-colonial space, a "relative space". This does not prevent behaviours such as the favouring of the expansion of neo-Pentecostalism in one location, or the preferential hiring of Brazilians in commerce in another - in Porto, for example - because of course, according to the mythology of Lusotropicalism, "Brazilians are always smiling". It is true that there are various cultures in these Lusophonies, but not at the global level of a Portuguesespeaking cultural community, unless it is limited to the PortugueseBrazilian area by itself.

All this can of course also be said of the Spanish-speaking, French-speaking and English-speaking worlds. However, in the Portuguese case, the imaginary was sharpened by the former metropolitan

6 We draw a distinction here between "post-colonial" as the chronological conception of a space that is thought to be, or still is, strongly influenced by its colonial heritage, and "postcolonial" as a specific theoretical approach that goes beyond (hence the "post") the colonial ideological legacies that are still present in literary and social science analyses. But this presents us with a linguistic difficulty, because in English "post-colonial" tends to mean precisely what we call postcolonial and póscolonial in French and Portuguese respectively. We maintain here, in English, the Franco-Portuguese distinction. 
centre's sense of its own weakness. This centre was incapable of constituting its own neo-colonial preserve or sphere as the French did - there is no "Lusáfrica", no Portuguese equivalent to the French "Françafrique". Angola and Mozambique have no sense of Portugal as the metropolis. ${ }^{7}$ The absence of a neo-colonial sphere is fortunate, and might even underpin a new type of North-South relationship, but at present it mainly serves to feed into the Portuguese government's disquiet at the prospect of other, better-financed powers encroaching on "África nossa" ("our Africa"). However, it is precisely the non-existence of a Portuguese sphere in Africa that allows us to say that the Portuguese language has been decolonized: there are many languages in Portuguese, in use from Timor to Brazil via Maputo and the Minho, but there is no common linguistic homeland, apart from tiny, globalised "Afro-Luso-Brazilian" social circles.

The "lightweight sense of identity" of Lusophony, this feeble metaidentity, reinforced by the commoditisation of the language, is advocated by those concerned when it is their interest to do so: this is the case with those Brazilians or Cape Verdeans who migrate to Portugal (often considering the move as a "step" towards "the true Europe"). On the other hand, one can point out that in the United States, over the long term, there is a complete lack of connection or even mere convergence between Brazilian-Americans, Portuguese-Americans and Cape Verdean-Americans (formerly known as "brown Portuguese"). In France, Belgium and Holland, where there are numerous Portuguese, Cape Verdean and Brazilian communities, there are few encounters and little or no sense of community. In Portugal, perhaps, we can see some bonds between Cape Verdeans and Brazilians, especially with regard to music.

Such a lightweight sense of identity is typical of the fluid situations that some describe as post-modern. It certainly does exist, but in a relative and contextual way, deeply rooted in [the multiple contexts of] the persistence of history (Carvalho \& Pina-Cabral 2007). That is why it can not be "reified" in a unified human community.

The geographical gigantism of Brazil (eighty times larger than Portugal, twenty times larger than France) and the political ambitions that this feeds; the fact that the PALOPs, while they are indeed states that have their place within Western structures such as the IMF, the World Bank, the WTO, and so on, nevertheless lack their own Western "metropolis"; Portugal's creation of the

7 This may be less true for Cape Verde and Guinea-Bissau. It does not prevent Angola's oil nomenklatura from going shopping in the luxury boutiques of Lisbon. 
Community of Portuguese-Speaking Countries (Comunidade dos Paises de língua portuguesa; CPLP) on 17 July 1996, and the role that the CPLP plays as a bridgehead to the other Portuguese-speaking countries - all these factors have strengthened Lusophony politically. However, contrary to what may be implied by the expression "Community of Portuguese-Speaking Countries", the CPLP can never constitute a community in the same way as the Commonwealth or the European Union. Its peculiarity lies in the fact that its leadership role cannot be guaranteed by the former colonial metropolis, because of its own modest economic and demographic weight - unlike the Sommet de la Francophonie or the Commonwealth. Nevertheless, Lusophony can play a not insignificant role at the interface of other geopolitical groupings. These include MercoSul (which Brazil belongs to); the European Union (with Portugal as a member); the Southern African Development Community (SADC), which Angola and Mozambique both belong to; the French-speaking West African Monetary and Economic Union (UMEOA), which Guinea-Bissau has joined; the Association of Southeast Asian Nations (ASEAN), including East Timor; and the Chinese sphere of influence through Macao, which became a Special Administrative Region of the People's Republic in 1999.

We have already quoted, because of its general applicability, the elegant turn of phrase of the Portuguese essayist Eduardo Lourenço, describing Lusophony as "a specific area of intersection with other identities". But in the interior of Mozambique or Goa, where nobody speaks Portuguese; or in Cape Verde, where everyone uses Creole and nobody speaks Portuguese at home; or at the "Afro-Brazilian" carnival of the Aguda people in Benin, which is celebrated in French - in these cases even Lourenço's cautious definition no longer works. Still, Goa, a State of the Indian Union, retains its slightly modified Portuguese surnames - D'Souza instead of de Souza - and its Roman legal code (which is not used anywhere else in India). The Catholic population of Goa is a minority, but it is still more numerous there than anywhere else in India. The old architecture acquiring new value as a tourist attraction, the right to drink alcohol - these things demonstrate that even if one is not in Lusophony, one is nevertheless in lusotopy.

This is why, to begin with, the sub-title of the journal Lusotopie "Enjeux contemporains dans les espaces lusophones" (Contemporary Issues in Lusophone Spaces) was incoherent with respect to the journal's actual main title. In 2002 this sub-title was expanded with a longer sentence, which was printed only in French: "Publication annuelle internationale de recherches politiques en sciences de l'homme, de la société et de l'environnement sur les lieux, pays et communautés d'histoire et de langue officielle ou nationale portugaises et luso-créoles" (An annual international publication of political research in 
the human, social and environmental sciences on the places, countries and communities with a Portuguese history and officially or nationally using the Portuguese and Luso-Creole languages).

This was still not satisfactory, and in 2003 the phrase "Enjeux contemporains dans les espaces lusophones" disappeared completely, and the sub-title, still only in French, became: "Recherches politiques internationales en sciences de l'homme, de la société et de l'environnement sur les lieux, pays et communautés issus de l'histoire et de la colonisation portugaises" (International political research in the human, social and environmental sciences on the places, countries and communities resulting from the history of Portuguese colonization).

In the last of the volumes published by Karthala in 2004, and in the volumes subsequently published by Brill from 2005 onwards, the subtitle, now trilingual, became: "Recherches politiques internationales sur les espaces issus de l'histoire et de la colonisation portugaises / Pesquisas políticas internacionais sobre os espaços oriundos da história e da colonização portuguesas / International Political Research on Spaces Stemming from Portuguese Colonization and History".

To begin with Lusotopie was published annually, but then started to come out twice a year. The way of thinking that had led to the journal's development also showed that lusotopy as a concept was both applicable and necessary in the social sciences. Would it also be possible, then, to conceive of "Francotopy", "Hispanotopy", and "Anglotopy", in distinction from the terms French-speaking (la francophonie), Spanish-speaking, and English-speaking or Anglophone? Yes, of course it would! But there are three specific characteristics that distinguish the Portuguese case. First, Portugal's great antiquity as a colonial power, beginning in 1416, when it captured Ceuta in Morocco, and the concomitant fact that this has resulted in many more significant Creole social strata (black, mixed-race, white) than with other colonising powers. Second, its decline was prolonged, which explains why many areas are no longer part of Lusophony but have remained at least partially within lusotopy. Third, the former "metropole" is by no means the most economically important Portuguese-speaking country. The concept of lusotopy thus becomes all the more necessary.

There was another consideration when it came to the journal: the objective was that it be considered generalist. But how could this happen, since it was so specialised? It was generalist because we are referring to a means, not to an end: the area of study was, above all, a field for empirical research, whose postcolonial relevance was just as acceptable as "Europe" or "the Western world", neither more nor less, but with one great heuristic advantage: by definition the area is extremely heterogeneous, and through its study one could therefore study the problems of the whole world. It follows then that the authors 
who published in Lusotopie were, above all, social scientists posing the general questions of their discipline and researching them in a field defined as the area impacted by Portuguese history and Portuguese colonization.

Thousands of pages ( 8,672 to be exact) of political analysis - in the broad sense - were published in Lusotopie between 1994 and 2009 and are today available online at the Persée and Revues.org websites. ${ }^{8}$ Authors of over thirty nationalities, including citizens of what we have, for twenty years now, referred to as the so-called "Global South", have been published in one of the journal's three working languages, with trilingual abstracts. ${ }^{9}$ By suggesting a decentralized view of the so-called Portuguese-speaking (Lusophone) world, one of the objectives has been to bring forward different ways of interrogating Portugal's colonial legacies, through the creation of a space for reflection, within which knowledge, and the relationships between researchers, would be decolonised, a collaborative space that would be as symmetrical as possible and far away from epistemological hegemonies. Such a challenge made the journal's intellectual project even more complex. The aim was 1) to question (or even challenge) the post-colonial dimension, in a chronological sense, of the areas studied - Brazil being a typical example of independence without decolonization (thus, is it "post-colonial"?); but, 2) - to keep postcolonial studies under critical surveillance, since, all too often, such studies remained trapped in the culturalism and national narratives from which they claimed that they were emancipating the social sciences (Smouts 2007).

A huge variety of themes, topics, lands, countries, and communities have been studied during these years. It is impossible to summarise them here. But only to give a glimpse, in a very unfair "selection", we could cite the limits of

8 The website Revues.org, despite its French name, was well known internationally. In the meantime, it has become OpenEdition Journals, which automatically means that, since the name is now in English, the quality improves significantly!

9 At the very beginning, in 1994, the project was entirely French: French was still an important language in Portugal and in Brazil, and the founders thought that a journal in a language other than Portuguese could be in French. Very quickly, however, articles began to be submitted in Portuguese, which ought to have been translated. In this way, empirically, we moved to bilingualism (in 1995) and then to trilingualism (in 1996), which became a hallmark of the journal with, roughly speaking, one-third in each language. It was an editorial space of linguistic equality for authors who could express themselves in three of the major global colonial languages - and in fact, the journal has also occasionally published in Spanish and Galician. 
political Lusophony (Cahen 1994, Léonard 1995), the "Eastern Question" in the colonial imagination of the Portuguese Communist Party (Manya 1994), the Lusotropicalist ideology in colonial Angola (Barbeitos 1997), the study of Afro-Brazilian cults (Guillot 2009), the categorizations of Brazilian immigrants (Machado 2004), the religious question from the least commonly used angle, that of Islam (Tiesler 2007), the question of "Afro-Atlanticity", obviously related to slavery, in the Cape Verde Islands (Margarido 1994) and to contemporary debates on "racial" heritage in the formation of the Brazilian nation (Macagno 2009), the model of paternalistic exploitation in the Brazilian Amazon (Geffray 1996), Goa and India seen not as the "Orient" but as paradigmatic examples of rupture (Siqueira 2002), a reflection on analogies between the Portuguese, Russian and Turkish-Ottoman empires (Derluguian 2007) and so on. Lusotopie was all that and more (see the figure below).

\begin{tabular}{|c|}
\hline Lusotopie issues, with indication of the main topics \\
\hline L'Harmattan (Paris) \\
\hline $\begin{array}{l}\text { - I (1-2)/1994, "Géopolitiques des mondes lusophones" (ed. M. Cahen), 1994, } \\
\quad 448 \text { p., ISBN: 2-7384-2360-4. }\end{array}$ \\
\hline Karthala (Paris) \\
\hline $\begin{array}{l}\text { - II/1995, "Transitions libérales en Afrique lusophone" (ed. M. Cahen), 1995, } \\
\text { 424 p., ISBN: 2-86537-618-4; }\end{array}$ \\
\hline $\begin{array}{l}\text { - III/1996, "Loppression paternaliste au Brésil" (eds P. Léna, C. Geffray \& } \\
\text { R. Araújo), july 1996, 464 p., ISBN : 2-86537-675-3; }\end{array}$ \\
\hline $\begin{array}{l}\text { - IV/1997, "Lusotropicalisme. Idéologies coloniales et identités nationales dans } \\
\text { les mondes lusophones" (eds D. Couto, A. Enders \& Y. Léonard), december }\end{array}$ \\
\hline $\begin{array}{l}\text { 1997, } 592 \text { p. + } 8 \text { p. photos, IS BN: 2-86537-784-9; } \\
\text { - V/1998, “Des protestantismes en 'lusophonie catholique'” (eds J.-P. Bastian, F; } \\
\text { Guichard \& C. Messiant), 1998, } 640 \text { p., ISB N: 2-86537-889-6; }\end{array}$ \\
\hline $\begin{array}{l}\text { - VI/1999, "Dynamiques religieuses en lusophonie contemporaine" (eds } \\
\text { J.-P. Bastian, F. Guichard \& C. Messiant), 1999, } 618 \text { p., IS BN: 2-86537-99o-6; }\end{array}$ \\
\hline $\begin{array}{l}\text { - VII/200o, "Lusophonies asiatiques, Asiatiques en lusophonies" (eds } \\
\text { M. Cahen, D. Couto, P. R. DeSouza, L. Marrou \& A. Siqueira), 2001, } 765 \text { pages, }\end{array}$ \\
\hline $\begin{array}{l}\text { ISBN: 2-84586-146-X); } \\
\text { - VIII/2001, “Timor, les défis de l'indépendance" (eds M. Cahen \& } \\
\text { I. Carneiro de Sousa), 2002, } 448 \text { p., ISBN: 2-84586-232-6; }\end{array}$ \\
\hline
\end{tabular}


- IX (1)/2002, "Les ONG en lusophonie. Terrains et débats" (eds B. Lachartre \& P. Léna), Karthala, 2002, 416 p., ISBN: 2-84586-307-1;

- IX (2)/2002, "Portugal, une identité dans la longue durée" (eds F. Guichard, L. A. de Oliveira Ramos \& M. Cahen, 2003, 272 p., ISBN: 2-84586-340-3;

- X/2003, "Violences et contrôle de la violence au Brésil, en Afrique et à Goa" (ed. C. Goirand), 2004, 578 p., ISBN: 2-84586-514-7;

- Book "Lusotopie": Jacky Picard (ed.), Le Brésil de Lula. Les défis d'un socialisme démocratique à la périphérie du capitalisme, 2003, 344 p., IS BN: 2-84586-410-8;

- XI/2004, "Médias, pouvoir et identités" (ed. M. Cahen, introduction de L. C. Patraquim), Karthala, 2005, 496 p., ISB N: 2-84586-594-5.

\section{Brill Publishing (Leyden-Boston), ISSN: 1257-0273}

- XII (1-2)/2005, "Genre et rapports sociaux dans les espaces lusophones / Gênero e relações sociais / Gendered social relationships” (eds M. Moormann \& K. Sheldon), $x i x+300$ p., ISBN: 90-04-14992-9,

- XIII (1)/June 2006, "Périphéries des villes, périphéries du monde / Periferias urbanas, periferias do mundo / Urban peripheries, global peripheries", iv + 216 p., IS BN: 90-04-15455-8;

- XIII (2)/November 2006, "Le politique par le bas / A política por baixo / Politics from below", iv + 248 p., ISBN: 90-04-15647-X;

- XIV (1)/June 2007, "Islam en lusophonies/ Islão nas lusofonias / Islam in Portuguese-speakingareas”(ed.N.C.Tiesler),iv+312p., Is BN:978-90-04-15565-7;

- XIV (2)/November 2007, "Lusomondialisation ? L'économie politique du Brésil de Lula" (eds B. Lachartre \& P. Salama), iv + 232 p., ISB N: 978-90-04-15566-4;

- XV (1)/June 2008 [parution septembre], "Indiens d'Afrique orientale" (eds Joana Pereira Leite \& Nicole Khouri), iv + 260 p., IS BN: 978-90-04-17012-4;

- XV (2)/November 2008, "Histoires d'Asie/Miscellanées", vi + 298 p., ISBN: 978-90-04-17013-1;

- XVI (1)/June 2009, "Afrique australe, Afrique lusophone. Mondes fragmentés, histoires liées" (eds Brigitte Lachartre \& Dominique Vidal), iv + 272 p., ISBN: 978-90-04-17881-6;

- XVI (2)/November 2009 [published February 2010], "Afrobrésiliennité ? Luso-afrobrésiliennité ? /Miscellanées”, xviii + 298 p., ISBN : 978-90-04-18339-1.

These issues may be accessed on https://www.persee.fr/collection/luso (19942004) and https://journals.openedition.org/lusotopie/ (2005-2009). It is still possible to buy almost all these issues (please contact the board). 
An institutional weakness of the journal was undoubtedly that, although it was assisted from the start by staff seconded from the Centre d'Étude d'Afrique Noire (CEAN) in Bordeaux, it was never actually based in a centre or institute. Michel Cahen was the editor-in-chief for 14 of the journal's 16 years, ${ }^{10}$ from 1994 to 2009, but after he stepped down CEAN could no longer justify to the CNRS the allocation of a part-time staff member. It was for this reason (among others) that Lusotopie - published annually in 1994 by L'Harmattan and by Karthala from 1995 to 2004, and twice-yearly by Brill in Leiden from 2005 to 2009 - then suspended publication. However, a decision to close the publication was never taken - hence suspension rather than termination. It has taken nine years to assemble a renewed and rejuvenated editorial team, and to secure support from a CNRS research centre - the Institut d'Ethnologie Méditerranéenne, Européenne et Comparative in Aix-en-Provence. Brill have agreed without hesitation to resume publishing the journal.

Has the concept of lusotopy found a place in the social sciences? The critique of Lusophony, especially the very ideology of Lusophony, has undoubtedly progressed since 1994, from the literary, political and economic perspectives. Some of the articles published in this issue and elsewhere demonstrate this, but this is a negative critique. The critique of the ideology of Lusophony does not provide us with an instrument for the understanding of historically-produced realities. These realities do not constitute a "common homeland", a phrase extracted and distorted from Fernando's Pessoa statement that "Minha Pátria é a língua portuguesa" - my homeland is the Portuguese language. Pessoa as a writer believed that the language was his homeland, but he did not believe at all that the Portuguese language had constituted a common homeland made up of the states that adopted it as their official language (Cahen 2007). The concept of lusotopy makes it possible, in the social sciences, to express realities outside neo-imperialist ideology. Some authors do deploy the concept but, let us say it bluntly: in our opinion, they are too few. Too many authors have remained only at the level of a critique of the myths of lusophony, a negative critique without any positive counter-proposals - and this is a justification for this special issue. Hopefully, the reappearance of the journal will also assist in revitalizing the debate around the concept.

Among those who do use the concept of lusotopy, is there complete conformity of opinion? Of course not: in the social sciences, it is a commonplace all is nuance. For the three founders of the journal - Messiant, Geffray and Cahen - lusotopy was first and foremost an area of specific historicity and

10 Armelle Enders, historian of Brazil, was editor-in-chief in 2001-2002. 
social trajectories, in other words an "objective reality". Nevertheless, this did not prevent the taking account of subjectivities as socially-rooted ideas. Some scholars, while completely rejecting the ideology of Lusofonia, and refusing to conflate lusotopy with Lusutopia - a "Lusitanian Utopia"11 dreamed up by others - granted to the former a subjective, affective, non-automatic dimension, not generalized, not permanent, but possible. Thus, João de Pina-Cabral uses the not-easily-translatable Latin idea of amicitia to denote not a "league of friendship" that would exist between all the "Lusophone" peoples, but a possibility, an affinity that may stimulate such friendship or mutual understanding, and manifests itself, according to circumstances, in sometimes fortuitous encounters between people from the countries of lusotopy. It may or may not occur, but if it does, then lusotopy is also a kind of consciousness. Although expressed in different words and within a geographer's problematic, Louis Marrou, who "invented" the concept at the beginning of the 1990s, seems to agree with this perspective of a subjective lusotopy. Nevertheless, other authors such as Michel Cahen support a more "objectivist" point of view. But all the authors make a radical distinction between Lusophony and lusotopy to the extent that it allows an escape from a "natural" articulation between language, culture and nation. Thus, Lusophony is opposed to the fluidity of the borders of lusotopy.

It is still necessary to consider how the individuals and communities who are today included, in an "objective" way, in this historical area, appropriate and make sense, if they can, of this "heritage". For example, some studies on contemporary migrations in lusotopy open up new lines of investigation that interrogate the subjective lusotopy, a kind of imaginary geography constituted by continuities but also by historical ruptures (Abadia et alii 2018, Dos Santos 2016). To inherit is not only to receive. It is also, and above all, to appropriate a past, to build a history and a memory: "a new narrative as a tool to assert one's own contemporary existence" to quote António Sousa Ribeiro and Margarida Calafate Ribeiro. The task is to get to know these new narratives, and to analyse the ways in which they are interwoven, in order to understand what lusotopian space(s) these historicities are building.

11 This "Lusutopia", as a neo-imperialist ideology, would then be diametrically opposed to the postimperial epistemology of Lusotopia (see note 6 about "post-colonial" and "postcolonial" to understand the similar distinction between "post-imperial" and "postimperial", which some describe as post-imperialist). On the postimperialist thesis, see for example Gustavo Lins Ribeiro (2001): "Why (post)colonialism and (de)coloniality are not enough: a post-imperialist perspective". We note that Lins Ribeiro wrote "post-imperialist" when we would have written the word without a hyphen. 
The new phase of Lusotopie, the journal, will have its own evolving characteristics, but the scientific and editorial orientation is likely, unless we are mistaken, to remain the same. In order to bridge the gap between the last issue of the first series, in December 2009, and the first number of the new series in September of 2018, it was decided to publish this special issue, consisting of two separate parts. The first part examines the concept of lusotopy and consists of original studies, as well as some texts published after 2009 (that is to say, after the end of the first series), here revised and expanded by their authors. The second section consists of two articles in Portuguese, already published in French and in English, but never in the language of Camões, by our late friends Christian Geffray (d. 2001) and Christine Messiant (d. 2006).

In the first section, we have attempted to bring together various aspects of the question. The very first chapter could only have been written by Louis Marrou, who explains how the concept of lusotopy germinated during his travels. The second chapter is an updated version of a provocative article first published in the Portuguese daily newspaper Público in 2013, by António Pinto Ribeiro: his objective was to put an end to the Lusotropicalist and Lusophone ideological slagging matches that plagued Portuguese national discourse. The third chapter, by Paulo de Medeiros, focuses on literary analysis, showing how the ghost of Lusophony still haunts us, preventing "the most rancid forms of nostalgia for a lost imperial greatness" from disappearing. The fourth chapter, already mentioned, is by João de Pina-Cabral, who explicitly argues in favour of using the concept of lusotopy to describe a network of networks - an ecumene - that permit, but do not imply, selective affinity. The fifth and sixth chapters of the first section address the issue of historical perspectives and "memory studies". Margarida Calafate Ribeiro and António Sousa Ribeiro argue that the "postmemory" of the colonial wars in Portugal represents a break in the silence that until recently enveloped this violent past. They suggest that this has opened the way for various critical voices on colonial and imperial Portuguese history that are finally being raised in the public space. Sébastien Rozeaux shows that in fact a lusotopy certainly existed before Lusophony did, citing the example of the Luso-Brazilian literary community of the nineteenth century. This community, which remained very localised, nevertheless managed to encourage, at least in Brazil, a particular attention to Portuguese literature, and thus, in this sense, an imagined community, without creating within the two peoples a sentiment of common affiliation on both sides of the Atlantic.

The second part of the dossier, as we have said, consists of two chapters that we consider theoretically fundamental. They do not focus specifically on lusotopy, but rather present archetypal examples of a generalist theorizing effort that is firmly rooted in lusotopy's field. They represent exactly what we 
have been attempting to do. Christine Messiant wanted her article (1999) to be published in Portuguese, preferably in Angola itself. But we failed to find an Angolan journal willing to publish such a critical article about the neo-patrimonialism of the Angolan regime. Subsequently the Portuguese and Brazilian journals that we contacted also refused, often arguing that they would only publish original articles, and not translations of already published articles. The article by Christian Geffray (200o) was translated into Portuguese posthumously, and we again encountered the same difficulties with the Portuguese and Brazilian journals that had refused Messiant's text. Although they are very different from each other, the two chapters deal with the important phenomenon of the relationship between authoritarian paternalism and neo-patrimonialism, a relationship that challenges the idea of the state as the ideal of the public good, in the most diverse societies. Is it not the case that the neo-imperialist ideology of Lusophony, mainly stemming from Lusotropicalism, is at the centre of this relationship?

Readers of the "new Lusotopie" journal will thus have a glimpse of an intellectual and scientific adventure that has not come to a halt, even though the journal stopped appearing between 2010 and 2018. The editorial of volume XVII (Dos Santos et alii 2018) - the first to appear after eight years of interruption - states that the question is still one of "creat[ing] greater horizontality and equality between America, Africa, Asia and Europe, the four great regions of the world that will be the focus of the journal" from the perspective of lusotopy.

\section{References}

Abadia, L. et alii eds. 2018, "Interwoven Migration Narratives: Identity and Social Representations in the Lusophone World", Identities. Global Studies in Culture and Power, 25 (3), accessed september, 23 2018. https://www.tandfonline.com/doi/ abs/10.1080/1070289X.2016.1244062?journalCode=gide20, DOI: 10.1080/1070289X .2016 .1244062 .

Barbeitos, A. 1997, “Une perspective angolaise sur le lusotropicalisme”, Lusotopie, IV: 309-326.

Cahen, M. 1994, "De Timor à Leticia, géopolitiques des mondes lusophones", Lusotopie, I (1-2): 19-33.

Cahen, M. 2007, "Lusitanité et lusophonie: considérations conceptuelles sur des réalités sociales et politiques", in A.-M. Binet (ed.), Mythes et mémoire collective dans la culture lusophone, Pessac, Presses Universitaires de Bordeaux: 127-146. 
Carvalho, C. \& Pina-Cabral J. de 2004, A persistência da história, Lisboa, Imprensa de Ciências Sociais.

Chrétien, J.-P. 2003, "Pourquoi l'Afrique, pourquoi l'histoire?", Afrique et Histoire, 1: 7-19. Derluguian, G. M. 2007, "The Worlds Which the Portuguese, the Russians, and the Turks Created: Empires on Europe's Periphery", Lusotopie, XIV (2): 3-10.

Dos Santos, I. 2016, "Angola, an Eldorado for Portuguese youth? Imagined worlds and experiences of mobility in the Lusophone area", Cahiers d'Études Africaines, 221-222: 29-52.

Dos Santos, I. et alii 2018, "Editorial", Lusotopie 17 (1): 7-9.

Geffray, C. 1996, "Le modèle de l'exploitation paternaliste", Lusotopie, III: 153-159.

Guillot, M. 2009, "Du mythe de l'unité luso-afro-brésilienne. Le candomblé et l'umbanda au Portugal", Lusotopie, XVI (2): 205-219.

Léonard, Y. 1995, “La 'Communauté des pays de langue portugaise', ou l'hypothétique lusophonie politique", Lusotopie, II: 9-16.

Macagno, L. 2009, "Les 'trois races' sont-elles solubles dans la nation ?Africanisme et nationalisme au temps de Lula », Lusotopie, XVI (2): 173-184.

Machado, I. J. de Renó 2004, "Imigrantes brasileiros no Porto Aproximação à perenidade de ordens raciais e coloniais portuguesas", Lusotopie, XI: 121-140.

Manya, J. 2000, "La 'question d'Orient' dans l'imaginaire national du Parti communiste portugais", Lusotopie, vir: 161-173.

Margarido, A. 1994, "Pour une histoire des géopolitiques des Îles du Cap-Vert", Lusotopie, I (1-2): 103-112.

Ribeiro, G. L. 2001, "Why (post)colonialism and (de)coloniality are not enough: a postimperialist perspective", Postcolonial Studies, XIV (3): 285-297.

Siqueira, A. 2002, "Postcolonial Portugal, Postcolonial Goa. A Note on Portuguese Identity and its resonance in Goa and India", Lusotopie, IX (2): 211-213.

Smouts, M.-C. ed. 2007, La situation postcoloniale, Paris, Les Presses de Sciences Po.

Tiesler, N. C. 2007, "Islam in Portuguese-Speaking Areas. Historical accounts, (post) colonial conditions and current debates", Lusotopie, XIV (1): 91-101.

Translated from French by Colin Darch, revised by Bradley Safarik. 